\title{
PERANCANG APLIKASI PENGENALAN LISTRIK KERAKYATAN BERBASIS MULTIMEDIA
}

\author{
Yasni Djamain, Widya Nita Suliyanti, Desi Rose Hertina \\ Teknik Informatika STT-PLN Jakarta \\ Email: yasni@sttpln.ac.id, widya.nita@sttpln.ac.id, desi.rose@sttpln.ac.id
}

\begin{abstract}
With the advancement of technology, there is an increased need of electricity. Listrik Kerakyatan (Grassroot Electricity) is a small scale electricity generation that is build together using easily obtained materials. There is a need to have a grassroots electricity software application based on multimedia to help society access information faster and easier. Presentation of information will be more interesting using multimedia. Multimedia is a technology that combines animation, pictures, audio and video delivered by an interactive computer system. Research result will be in a form of software application for grassroots electricity that will make society obtain information about electricity easier and faster.
\end{abstract}

Kata kunci : Listrik kerakyatan, Multimedia, Prototype

\section{PENDAHULUAN}

\subsection{Latar Belakang}

Energi listrik merupakan kebutuhan utama kehidupan masyarakat modern. Untuk memenuhi listrik masyarakat, industri dan instansi yang semakin meningkat pemerintah telah banyak membangun dan mengembangkan pembangkitpembangkit listrik dengan berbagai jenis tenaga pengerak, mulai dari; tenaga air, pembangkit listrik tenaga uap, pembangkit listrik tenaga nuklir. Listrik Kerakyatan didefinisikan sebagai suatu model penyediaan dan pengembangan energi listrik yang terdiri dari bauran pembangkit sederhana skala kecil dari energi bersih yang tersedia disekitar komunitas masyarakat sehingga dapat dibangun sendiri dilakukan secara bergotong royong oleh berbagai kelompok masyarakat di tingkat kelurahan di seluruh tanah air. Jika ingin mengetahui cara pembuatan listrik

kerakyatan, masyarakat harus datang ke STT-PLN karena penerapan listrik kerakyatan salah satunya berada di STT-PLN. Berdasarkan observasi yang telah dilakukan di Tangerang, masih banyak masyarat yang belum mengetahui tentang listrik kerakyatan ini. Dan masih banyak pula yang ingin meng-implementasikan namun tidak mengerti bagaimana tahapan untuk membuat listrik kerakyatan. Sehingga masyarakat kurang memahami cara kinerja dari sistem tersebut. Hal ini dapat diatasi dengan pemanfaatan berbasis Multimedia.

Hingga saat ini belum adanya aplikasi yang dapat membantu tim listrik kerakyatan untuk lebih memperkenalkan energi tersebut. Dari salah satu masalah tersebut, penulis mengusulkan untuk digunakannya metode multimedia untuk menarik minat masyarakat untuk lebih mengenal listrik kerakyatan ini. Multimedia juga mampu memudahkan penyampaian informasi karena menggunakan perpaduan gambar, video dan suata dibandingkan dengan cara penyampaian materi lainnya.

\subsection{Rumusan Masalah}

Berdasarkan latar belakang dan identifikasi masalah di atas, dapat di rumuskan permasalahan sebagai berikut : Bagaimana cara membangun multimedia listrik kerakyatan untuk memudahkan masyarakat memahami proses pengolahan sampah menjadi listrik?

\subsection{Tujuan dan Manfaat Penelitian}

Adapun tujuan yang ingin dicapai dari penelitian ini adalah menghasilkan aplikasi Multimedia listrik kerakyatan untuk sosialisasi di daerah Tangerang. Penelitian ini dilakukan dengan harapan dapat memberikan manfaat, diantaranya :

1. Mempermudah masyarakat mendapatkan informasi Listrik kerakyatan.

2. Masyarakat dapat lebih mudah memahami proses pengolahan sampah menjadi energi listrik yang dapat diterapkan oleh masyarakat.

\section{TINJAUAN PUSTAKA}

\subsection{Listrik Kerakyatan}

Listrik kerakyatan didefinisikan sebagai suatu model penyediaan dan pengembangan energi listrik yang terdiri dari bauran pembangkit sederhana skala kecil dari energi bersih yang tersedia disekitar komunitas sehingga dapat dibangun sendiri, dilakukan secara bergotong royong oleh berbagai kelompok masyarakat di tingkat kelurahan di seluruh tanah air. (Legino, 2016).

Listrik Kerakyatan bisa dibangun di perkotaan dengan bahan bakar sampah dan juga di daerah terpencil dengan bahan bakar biomassa tanaman. Listrik Kerakyatan bisa digangun di dekat dengan jaringan distribusi PLN karena tidak memerlukan jaringan transmisi tegangan tinggi yang mahal dan sarat dengan permasalahan. 


\section{Multimedia}

Multimedia merupakan perkembangan teknologi komputer yang saat ini menjadi perhatian luas. Istilah multimedia digunakan untuk menjelasan suatu sistem yang teridri dari perangkat keras (hardware) dan perangkat lunak (software), serta alat bantu lain yang berupa televisi, monitor video, dan sistem piringan optik atau sistem stereo yang semuanya dikombinasikan untuk menghasilkan suatu penyajian audio visual penuh (Mc Leod, 1996).

Multimedia diartikan sebagai kombinasi dari macam - macam objek multimedia, yaitu teks, image, animasi, audio, video, dan link interaktif untuk menyajikan informasi. Sedangkan Gayeski (1993) mendefinisikan multimedia sebagai kumpulan media berbasis komputer dan sistem komunikasi yang berperan untuk membina, menyimpan, mengirim dan menerima informasi yang berisi teks, grafik, audio dan sebagainya (Sutopo, 2003).

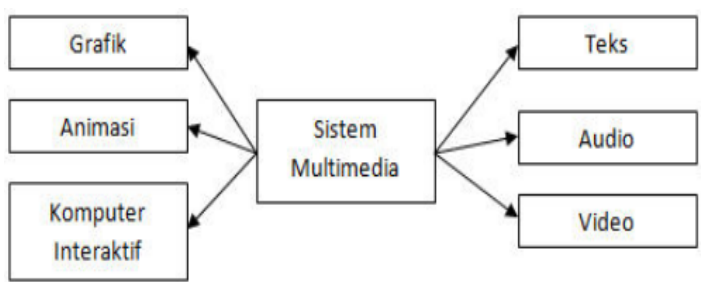

Gambar 1. Keterkaitan antara Multimedia

Dari beberapa pernyataan di atas dapat dikatakan bahwa multimedia merupakan penyatuan dua atau lebih media komunikasi seperti teks, grafik, animasi, audio dan video dengan ciri-ciri interaktif komputer untuk menghasilkan satu tampilan yang menarik. Pada awal tahun 1990-an yang dimaksud dengan multimedia adalah kombinasi antara teks dan gambar. Seiring dengan berkembangnya teknologi komputer dari waktu ke waktu, saat ini multimedia tidak hanya merupakan kombinasi dari teks dan gambar saja, melainkan telah menggunakan animasi, video, dan suara.

\section{Tahap Pengembangan Multimedia}

Pengembangan multimedia dilakukan berdasarkan enam tahap. Adapun penjelasan dari langkah-langkah pengembangan multimedia pada gambar di bawah ini:

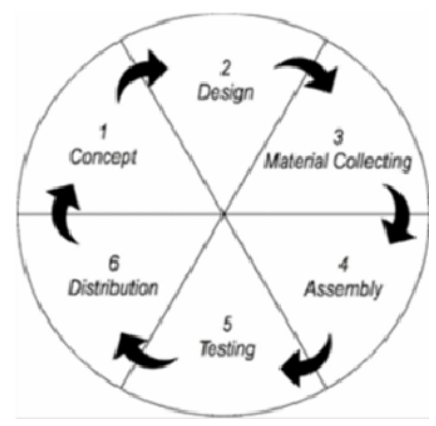

Gambar 2. Tahap Pengembangan Multimedia (Luther, 1994)
Adapun penjelasannya adalah sebagai berikut:

\section{Concept}

Tahap concept (konsep) yaitu menentukan tujuan, termasuk identifikasi pengguna, macam aplikasi (persentasi, interaktif, dan lain-lain), tujuan aplikasi (informasi, hiburan, pelatihan, dan lain-lain) dan spesifikasi umum. Dasar aturan untuk perancangan juga ditentukan pada tahap ini, seperti ukuran aplikasi, target, dan lain- lain.

\section{Design}

Maksud dari tahapan design (perancangan) adalah membuat spesifikasi secara rinci mengenai arstitektur proyek, gaya, dan kebutuhan material untuk proyek. Spesifikasi dibuat cukup rinci sehingga pada tahap berikutnya, yaitu material collecting dan assembly tidak diperlukan keputusan baru, tetapi menggunakan apa yang sudah ditentukan pada tahap design. Namun demikian, sering terjadi penambahan bahan atau bagian aplikasi ditambah, dihilangkan, atau diubah pada awal pengerjaan proyek.

\section{Material Collecting}

Material collecting (pengumpulan bahan) dapat dikerjakan paralel dengan tahap assembly. Pada tahap ini dilakukan pengumpulan bahan seperti clipart image, animasi, audio, berikut pembuatan gambar grafik, foto, audio, dan lain-lain yang diperlukan untuk tahap berikutnya. Bahan yang diperlukan dalam multimedia dapat diperoleh dari sumber-sumber seperti library, bahan yang sudah ada pada pihak lain, atau pembuatan khusus yang dilakukan oleh pihak luar.

\section{Assembly}

Tahap assembly (pembuatan) merupakan tahap dimana seluruh objek multimedia dibuat. Pembuatan aplikasi berdasarkan story board, flowchart view, struktur navigasi, atau diagram objek yang berasal dari tahap design. Contohnya pada pembuatan presentasi, pembuatan dilakukan dengan memasukkan data yang digunakan untuk berbagai tampilan, serta menentukan screen dengan urutannya.

\section{Testing}

Testing dilakukan setelah selesai tahap pembuatan dan seluruh data telah dimasukkan. Pertama-tama dilakukan testing secara modular untuk memastikanapakah hasilnya seperti yang diinginkan. Beberapa sistem mempunyai fitur yang dapat memberikan informasi bila terjadi kesalahan pada program. Suatu hal yang tidak kurang penting adalah aplikasi harus dapat berjalan dengan baik dilingkungan user. User merasakan kemudahan serta manfaat dari aplikasi tersebut dan dapat menggunakan sendiri terutama untuk aplikasi interaktif. 


\section{Distribution}

Bila aplikasi multimedia akan digunakan dengan mesin yang berbeda, penggandaan menggunakan floppy disk, CD-ROM, tape, atau distribusi dengan jaringan sangat diperlukan. Suatu aplikasi biasanya memerlukan banyak file yang berbeda, dan kadang-kadang mempunyai ukuran sangat besar.

\subsection{Multimedia Content Production}

Multimedia adalah penggunaan dan pemrosesan beberapa media (text, audio, graphics, animation, video, and interactivity) yang berbeda untuk menyampaikan informasi atau menghasilkan produk multimedia (music, video, film, game, entertaiment, dan lain-lain) Atau penggunaan sejumlah teknologi yang berbeda yang memungkinkan untuk menggabungkan media (text, audio, graphics, animation, video, and interactivity) dengan cara yang baru untuk tujuan komunikasi.

Dalam kategori ini media yang digunakan (tampak pada Gambar 3) adalah media text, media audio, media video, media animasi, media graph / image, media interactivity, dan media special effect.

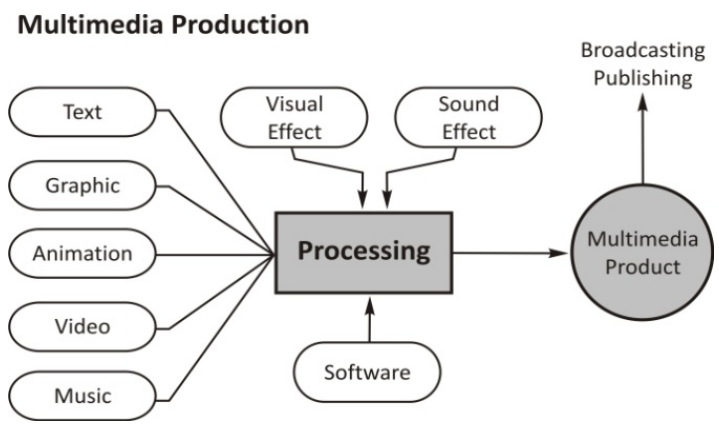

Gambar 3. Multimedia Production

\subsection{Multimedia Linear dan Multimedia Interaktif}

Multimedia terbagi menjadi dua kategori, yaitu: multimedia linear dan multimedia interaktif.

\section{Multimedia linear}

Multimedia linear dimulai dari satu posisi awal menuju ke suatu posisi akhir dengan sedikit atau tanpa interferensi pemakai. Misalnya televisi, film, majalah, koran. Pemakai hanya menjadi penonton dan menikmati produk multimedia yang disajikan dari awal hingga akhir.

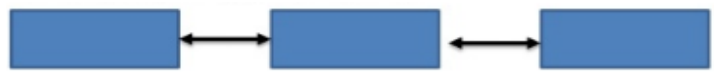

Gambar 4. Diagram Multimedia Linear

Ciri-ciri dari multimedia linear :

- Sederhana

- Bersifat logical

_ Ideal untuk produk yang kecil

2. Multimedia interaktif

Multimedia interaktif adalah integrasi digital antara text, graphics, animasi, audio, gambar tak bergerak (still images) dan bergerak (motion video) dimana disediakan kontrol terhadap konten dan interaksi tingkat tinggi bagi pemakai individu dan aplikasi multimedia. Misalnya game, multimedia pembelajaran, website. Pengguna dapat mengontrol apa dan kapan elemen-elemen multimedia akan dikirimkan atau ditampilkan.

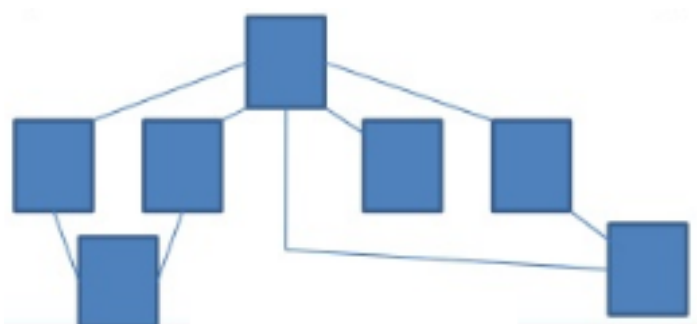

Gambar 5. Diagram Multimedia Interaktif

\section{Macromedia Flash 8}

Aplikasi Macromedia Flash 8 adalah sebuah program animasi yang telah banyak digunakan oleh designer untuk menghasilkan design yang professional. Diantara program-program animasi yang ada, program Macromedia Flash merupakan program yang paling fleksibel untuk membuat animasi, mulai dari animasi sederhana sampai animasi kompleks yang meliputi aplikasi web yang dinamis dan interaktif seperti ecommerece atau toko online di internet dan multimedia untuk pembuatan sebuah sistem informasi sehingga banyak yang menggunakan program tersebut. Fungsi program Macromedia Flash 8 adalah membuat animasi, baik animasi interaktif maupun animasi non interaktif.

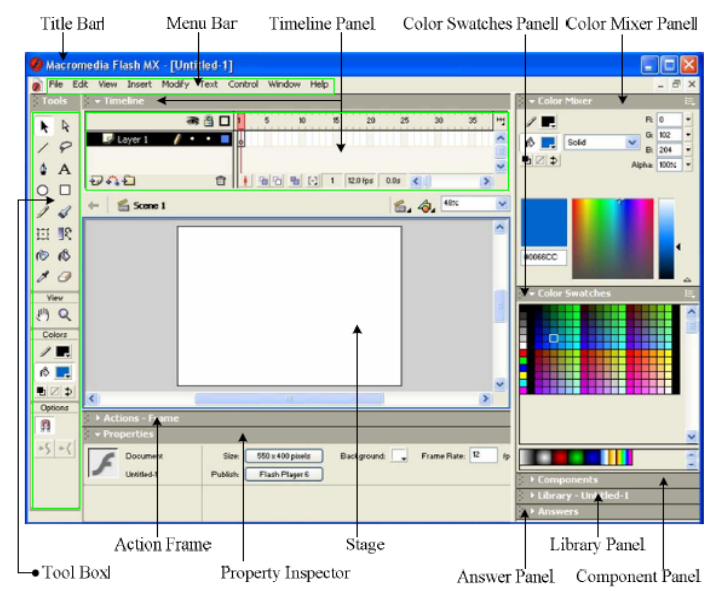

Gambar 6. Macromedia Flash 8

\section{METODOLOGI}

\subsection{Analisa Sistem Berjalan}

Listrik merupakan kebutuhan utama kehidupan masyarakat modern. Untuk memenuhi listrik masyarakat, industri dan instansi yang semakin meningkat pemerintah telah banyak membangun dan mengembangkan pembangkitpembangkit listrik dengan berbagai jenis tenaga 
pengerak, seperti tenaga air, pembangkit listrik tenaga uap, pembangkit listrik tenaga nuklir.

Listrik Kerakyatan didefinisikan sebagai suatu model penyediaan dan pengembangan energi listrik yang terdiri dari bauran pembangkit sederhana skala kecil dari energi bersih yang tersedia disekitar komunitas masyarakat sehingga dapat dibangun sendiri dilakukan secara bergotong royong oleh berbagai kelompok masyarakat di tingkat kelurahan di seluruh tanah air. Jika ingin mengetahui cara pembuatan listrik kerakyatan, masyarakat harus datang ke STT-PLN karena penerapan listrik kerakyatan salah satunya berada di STT-PLN. Masih banyak yang ingin mengimplementasikan namun tidak mengerti tahapan untuk membuat listrik kerakyatan. Sehingga masyarakat kurang memahami cara kinerja dari sistem tersebut. Hal ini dapat diatasi dengan pemanfaatan berbasis Multimedia.

\subsection{Kendala yang Dihadapi}

Hingga saat ini belum adanya aplikasi yang dapat membantu tim listrik kerakyatan untuk lebih memperkenalkan energi tersebut. Dari salah satu masalah tersebut, penulis mengusulkan untuk digunakannya metode multimedia untuk menarik minat masyarakat untuk lebih mengenal listrik kerakyatan ini.

Multimedia juga mampu memudahkan penyampaian informasi karena menggunakan perpaduan gambar, video dan suata dibandingkan dengan cara penyampaian materi lainnya.

\subsection{Alternatif Penyelesaian Masalah}

Dibutuhkannya aplikasi listrik kerakyatan berbasis Multimedia yang dapat membantu masyarakat untuk mengakses informasi lebih cepat dan mudah. Suatu informasi akan lebih menarik dengan adanya multimedia, karena ditampilkan dalam suatu bentuk penyajian yang merupakan gabungan dari berbagai bentuk elemen yang nantinya akan disajikan dalam bentuk gambar yang dapat bergerak maupun tidak bergerak serta dapat disajikan pula dalam bentuk teks, bahkan dalam bentuk audio dan video. Multimedia merupakan suatu teknologi yang menggabungkan berbagai tersebut dan disampaikan melalui suatu sistem komputer secara interaktif. Hasil dari penelitian yang dilakukan akan dibuat Aplikasi informasi listrik kerakyatan yang akan mempermudah masyarakat dalam mengakses informasi listrik lebih cepat dan mudah.

\subsection{Metodologi Penelitian}

Berikut ini adalah diagram alir penelitian yang penulis lakukan yang berisiskan tahap proses awal pembuatan hingga akhir penyusunan yaitu:

1. Pembuatan Konsep

Tahap pertama adalah pembuatan konsep, dimana dalam tahap ini terdapat beberapa langkah yaitu menentukan macam aplikasi yang akan di buat dan menentukan tujuan dari aplikasi.

2. Analisa Kebutuhan Sistem

Pada tahap ini dilakukan identifikasi pengguna dan mengumpulkan data dan bahan yang diperlukan dalam pembuatan aplikasi. Data pendukung yang diperlukan dalam penelitian ini yaitu dilakukan dengan:

- Mengadakan observasi dan wawancara pada pihak-pihak yang berkaitan dengan penelitian yang dilakukan.

- Studi pustaka dan internet untuk melengkapi data-data selain yang didapat dari observasi dan wawancara.

3. Pembuatan Design

Pada tahap pembuatan design, terdapat beberapa langkah yaitu membuat struktur hierarki, membuat STD, membuat storyboard, serta merancang interface.

4. Pembuatan system dan Pengkodean

Pada tahap ini dilakukan pembuatan aplikasi, yaitu menggunakan Macromedia Flash 8, serta dilakukan penulisan actionscript untuk program animasi yang telah di buat.

5. Uji Coba

6. Penulisan Laporan

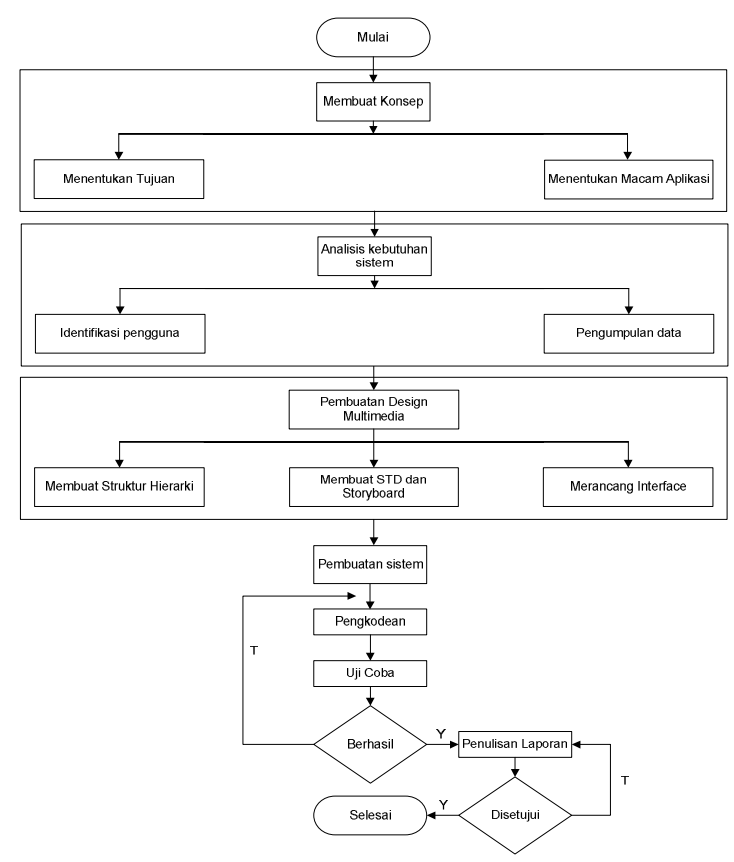

Gambar 7. Diagram Alir Pembuatan Multimedia

Peralatan yang digunakan untuk mengolah data secara umum adalah komputer, printer, alat tulis, dan peralatan pendukung lainnya. Adapun spesifikasi utama dari perangkat lunak dan perangkat keras yang penulis gunakan adalah sebagai berikut:

1. Perangkat Keras

Adapun perangkat keras yang penulis gunakan dalam merancang aplikasi multimedia ini adalah:

- 1 unit PC, dengan spesifikasi : Processor Intel(R) Core 2 Duo, CPU 3.00GHz 3.02 GHz, VGA:512 MB, Memory (RAM):1.00 GB.

- Mouse

- Keyboard

- Printer

- $\quad$ Monitor dengan resolusi 1024 x 768 
2. Perangkat Lunak

Perangkat lunak yang digunakan dalam merancang system ini adalah sebagai berikut: Operating System: Windows XP

Propessional

Microsoft Office Word 2007

Microsoft Visio 2007

Total Video Converter

Macromedia Flash 8

Macromedia Flash 8 adalah salah satu program animasi yang banyak digunakan oleh para animator atau designer untuk menghasilkan karyakarya profesional, khususnya di bidang animasi. Program ini cukup fleksibel untuk keperluan pembuatan animasi.

\section{HASIL DAN PEMBAHASAN}

Pelaksanaan Pengabdian Pada Masyarakat yaitu berupa multimedia yang bertujun untuk menjelaskan pengolahan sampah menjadi energi listrik. Diharapkan masyarakat dapat memperoleh gambaran mengenai energi lain yang menghasilkan listrik. Adapun tampilan multimedianya adalah sebagai berikut:

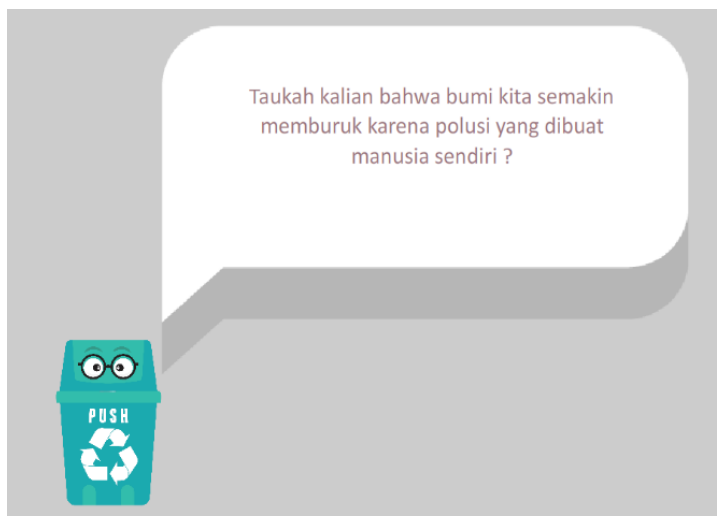

Gambar 8. Scene 1

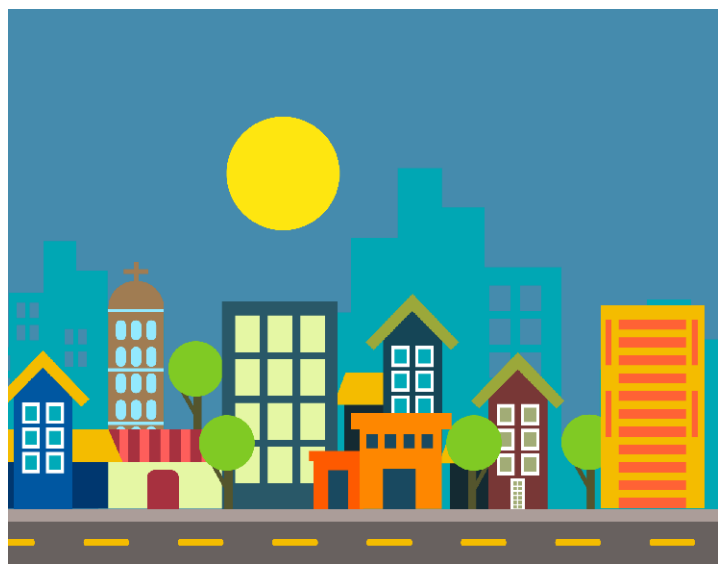

Gambar 9. Scene 2

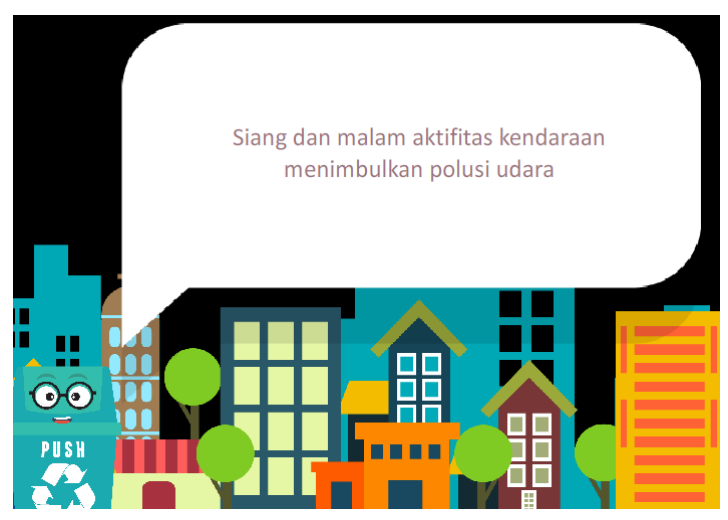

Gambar 10. Scene 3

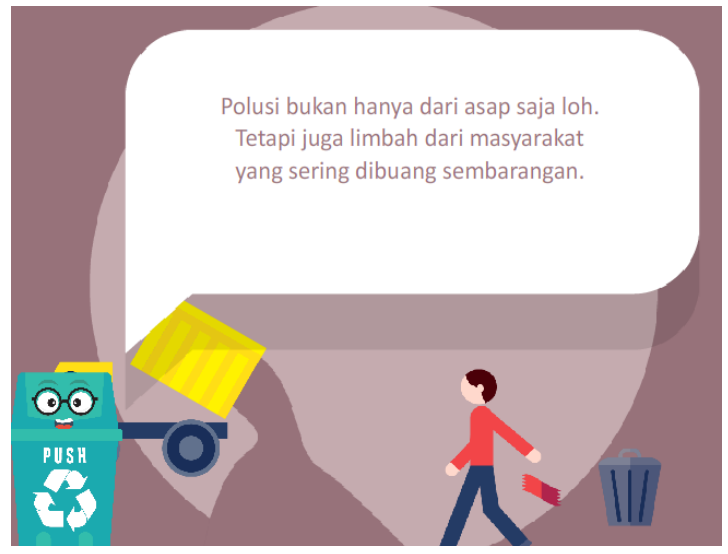

Gambar 11. Scene 4

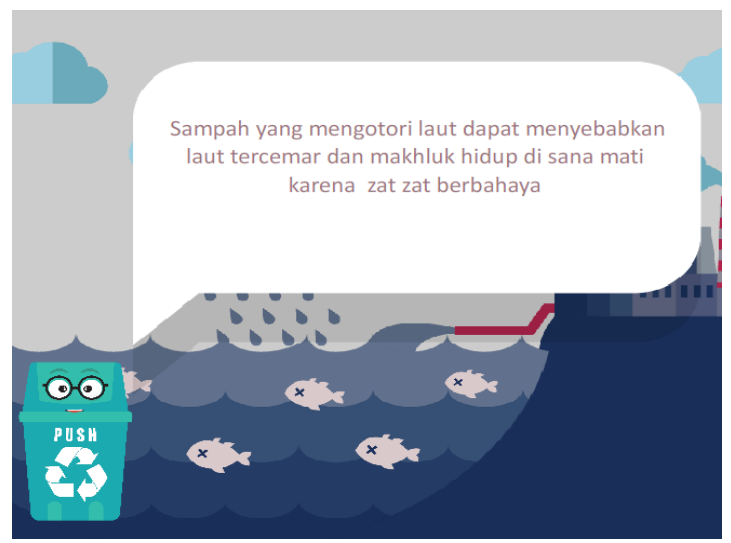

Gambar 12. Scene 5

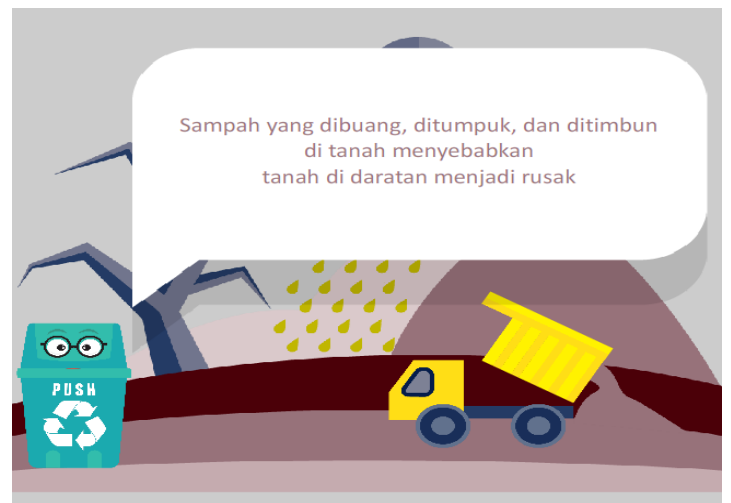

Gambar 13. Scene 6 


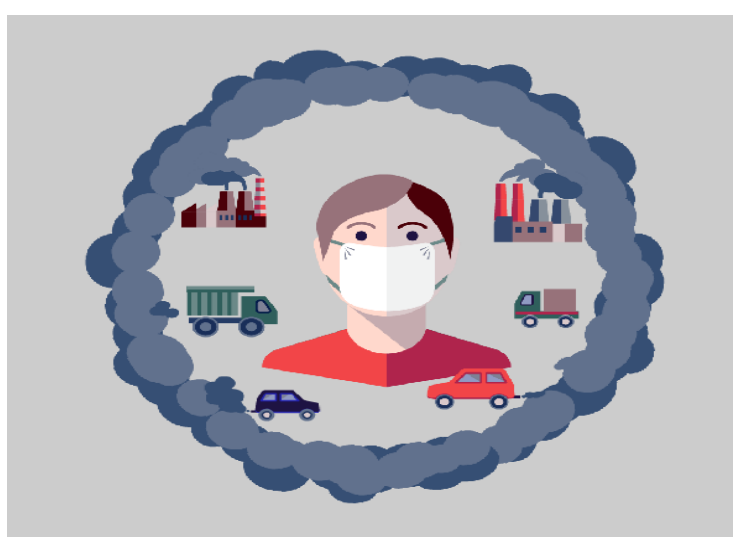

Gambar 14. Scene 7

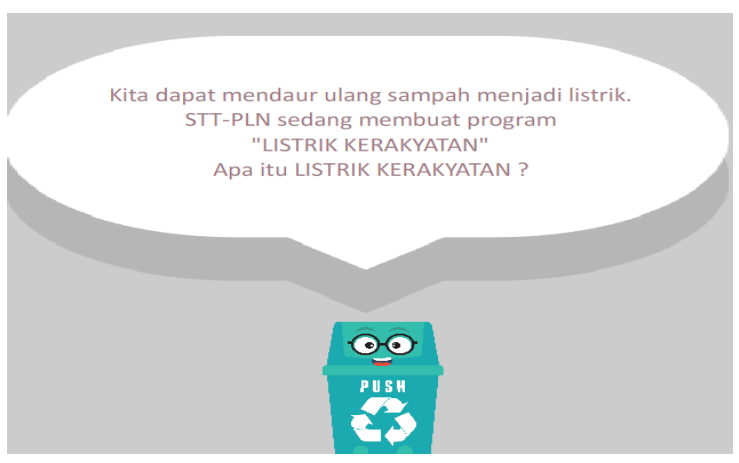

Gambar 15. Scene 8

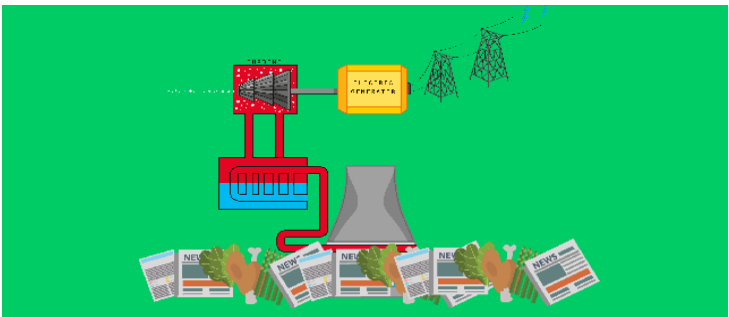

Langkah 1 Sampah yang ada dipilah antara Organik dan Non Organik

Gambar 16. Scene 9
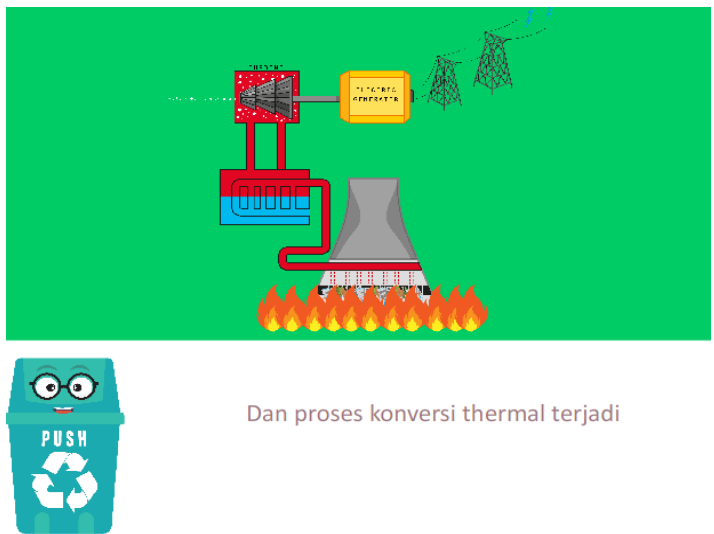

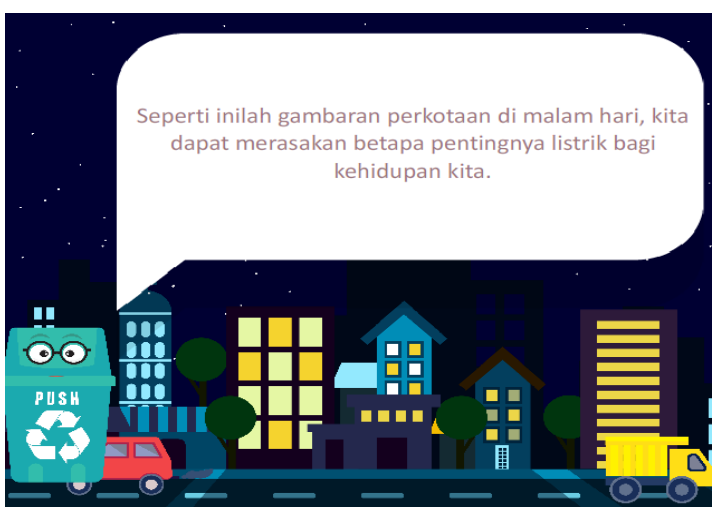

Gambar 18. Scene 11

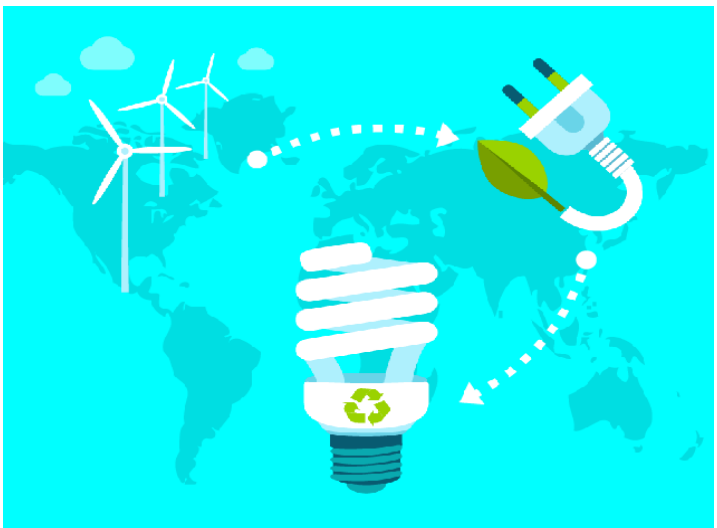

Gambar 19. Scene 12

\section{PENUTUP}

\subsection{Kesimpulan}

Dari P2M yang dilakukan dapat diambil beberapa kesimpulan yaitu:

- Para guru sangat mendukung multimedia tentang pengolahan sampah menjadi energi listrik.

- Sosialisasi tentang pemanfaatan sampah dapat menambah pengetahuan masyarakat tentang energi alternative penghasil listrik. Dengan adanya multimedia maka proses pengolahan tersebut dapat disampaikan dengan baik.

\subsection{Saran}

Adapun saran adalah sebagai berikut:

Multimedia dapat dimanfaatkan secara maksimal dengan memberikan sosilisasi kepada sekolah atau komunitas lain.

Perlunya multimedia yang lebih rinci menjelaskan proses pengolahan tersebut.

Gambar 17. Scene 10 


\section{DAFTAR PUSTAKA}

1. Luther, Arc. C. 1994. Authoring Interactive Multimedia. San Fransisco: A.P. Professional.

2. Supriatna, Nana. 2006. IPS Terpadu. Jakarta: Grafindo Media Pratama.

3. Sutopo, Ariesto Hadi. 2003 Multimedia Interaktif Dengan Flash. Yogyakarta: Graha IImu.

4. Sutardi, Tedi. 2007. Antropologi. Bandung: PT Setia Purna Inves.

5. Vaughan. Tray. 1994. Multimedia Making it Work Second Edition. Barkeley, USA: Osborne Mcgrawhill.

6. Yudhiantoro, Dhani. 2003. Paduan Lengkap Macromedia Flash MX. Yogyakarta : Andi Yogyakarta.

7. Supriadi Legino, Inisiatif istrik Kerakyatan Yang Ramah Lingkungan, Jakarta. 